\title{
DDA1 wt Allele
}

National Cancer Institute

\section{Source}

National Cancer Institute. DDA1 wt Allele. NCI Thesaurus. Code C119626.

Human DDA1 wild-type allele is located in the vicinity of 19p13.11 and is approximately 14 $\mathrm{kb}$ in length. This allele, which encodes DET 1- and DDB1-associated protein 1, may play a role in the regulation of protein ubiquitination. 